\title{
TL dating of Upper Palaeolithic sites in the Coa Valley (Portugal)
}

\author{
Hélène Valladas ${ }^{\mathrm{a}, *}$, Norbert Mercier ${ }^{\mathrm{a}}$, Laurence Froget ${ }^{\mathrm{a}}$, Jean Louis Joron ${ }^{\mathrm{b}}$, \\ Jean Louis Reyss ${ }^{\mathrm{a}}$, Thierry Aubry ${ }^{\mathrm{c}}$

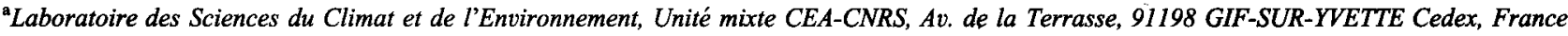

${ }^{\mathrm{b}}$ Laboratoire Pierre Süe, Groupe des Sciences de la Terre, CEN Saclay, 91191 GIF-SUR-YVETTE, France
\end{abstract} \\ 'Parque Arqueologico do Vale do Côa, Av. Gago Coutinho 19, 5150 VILA NOVA DE FOZ COA, Portugal
}

\begin{abstract}
In 1992, numerous animal engravings in styles associated with the Upper Palaeolithic (Gravetian to Magdalenian) were discovered along a long stretch of the schist cliffs bordering the Côa Valley (Northern Portugal). This suggested that not only caves and rock-shelters but also open-air Pleistocene sites may have been decorated in this manner more often than previously believed. Attempts to date the engravings themselves (radiocarbon of patination, micro-erosion analysis) were unsatisfactory, yielding contradictory and widely scattered dates.

We are now reporting thermoluminescence ages of 15 burnt quartzite pebbles excavated in 1997 at three sites (Cardina, Olga Grande Sul, Quinta da Barca Sul) near the decorated cliffs. The ages of the Cardina and Olga Grande Sul pebbles indicated human presence at the sites between 30 and $27 \mathrm{ka}$ ago, during the Gravetian period. The Quinta da Barca Sul pebbles were 13-10 ka old, indicating that humans were also present in the Valley during the Magdalenian period. (C) 2000 Elsevier Science Ltd. All rights reserved.
\end{abstract}

\section{Introduction}

Since 1995 several attempts have been made to date directly the rock engravings of the Côa valley, but the AMS radiocarbon dates of organic inclusions trapped in cracks (Dorn, 1997) and micro-erosion studies of the scratched surface (Bednarik, 1997) gave widely dispersed and contradictory ages (Zilhâo, 1997). Since dates obtained by these and other related techniques depend on the environmental conditions in the vicinity of the cliffs, it was decided to try and date the archaeological remains uncovered during excavation work in the valley. Cooperating in this dating project were the Instituto Português de Arqueologia (Lisbon), the Instituto Tecnologico e Nuclear (Lisbon) and the Laboratoire des Sciences du Climat et de l'Environnement (Gif sur Yvette).

When poor conservation of the excavated organic remains made radiocarbon dating unreliable we decided to establish the Côa Valley occupation chronology on the basis of the TL (Aitken, 1985; Mercier et al., 1995) of burnt quartzite excavated from palaeolithic hearths near the engravings. To-date we have examined lithics from

\footnotetext{
Paper published in December 2000.

* Corresponding author.
}

three sites: Cardina, Olga Grande Sul, and Quinta da Barca Sul (Fig. 1).

\section{Specimens}

To be able to select more efficiently lithic specimens suitable for dating we constructed an experimental outdoor hearth into which we placed some quartzite pebbles collected from a nearby river and resembling the archeological specimens. The pebbles were covered with kindle wood, a fire was lit and kept going with tree branches for about $2 \mathrm{~h}$. Prior experiments have shown that, under such conditions, stones weighing a few hundred grams attain temperatures in excess of $450^{\circ} \mathrm{C}$ (Valladas, 1981). The burnt pebbles were split or fractured and their surface changed from the original grey or $\tan$ to various shades of red and black. From among the palaeolithic remains of the three archaeological sites we were able to select 25 quartzite specimens (weighing between 50 and $200 \mathrm{~g}$ ) that were similar in appearance to the pebbles burnt in our hearth.

Examination of the TL glow curves of these specimens revealed that only 15 of the selected archaeological burnt lithics had been exposed to high enough temperatures to be suitable for TL dating. Seven came from Cardina 


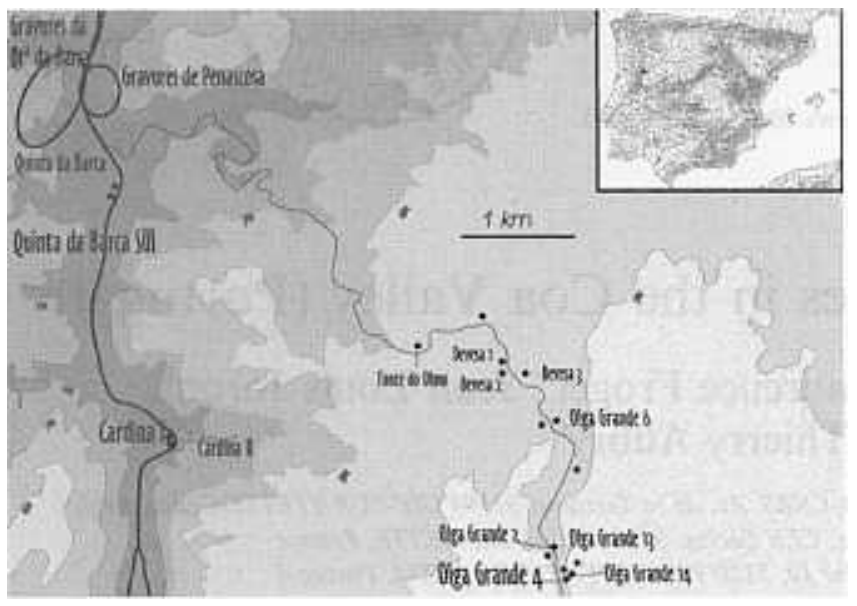

Fig. Location of the Côa valley prehistoric sites.

(level 4, Gravetian), five from Olga Grande Sul (level 3, Gravetian), and three from Quinta da Barca (level 2, Magdalenian). The other palaeolithic levels (Solutrian and Magdalenian) of the three sites have not yet yielded lithics dateable by TL.

Thin sections of the archaeological specimens showed that the principal component was quartz, sometimes accompanied by biotites, zircons, and apatites. The mean grain size of quartz within the selected specimens ranged from 50 to $700 \mu \mathrm{m}$. The siliceous binder represented $<5 \%$ of the weight.

\section{Radiometric parameters and age estimates}

The paleodose of the burnt lithic specimens was determined by the technique proposed by Mercier (Mercier et al., 1992) in which the TL growth curve obtained during the first heating (TL1 $=$ NTL + ATL) is compared with the regenerated TL growth curve (TL2 $=$ ATL). After the central core of each quartzite pebble was crushed and sieved (Valladas, 1992), powder in the $100-160 \mu \mathrm{m}$ range was collected and divided into two portions. After three aliquots of the first portion received incremental $\gamma$ doses from a calibrated ${ }^{137} \mathrm{Cs}$ source, their TL was measured on an automatic apparatus (Valladas et al., 1994) equipped with a Thorn EMI 9635 QB photomultiplier and an MTO $380 \mathrm{~nm}$ optical filter that selected the blue component of the emission spectrum; the heating rate was $5^{\circ} \mathrm{C} / \mathrm{s}$. In Fig. 2 are plotted the TL glow curves obtained after the specimen Cardina 10 received additional doses of 55,110 , and $165 \mathrm{~Gy}$. Between 280 and $400^{\circ} \mathrm{C}$, the NTL and artificial thermoluminescence, each gave a glow curve with two distinct maxima, at 310 and $390^{\circ} \mathrm{C}$. The measurements were done on $15 \mathrm{~mm}$ wide cups containing $10 \mathrm{mg}$ of powder and were reproducible to within $2-3 \%$. The second portion of the powder was heated for

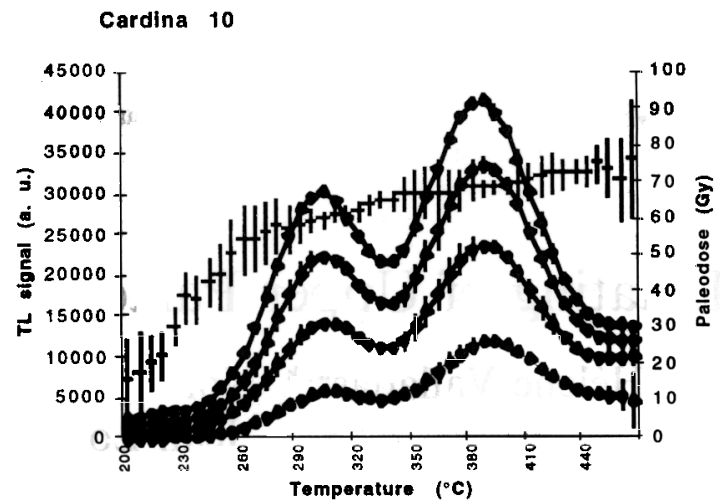

Fig. 2. TL glow curves of Cardina 10 recorded between 200 and $460^{\circ} \mathrm{C}$ : natural TL and natural plus artificial TL induced, respectively, by the added doses of 55, 110 and $165 \mathrm{~Gy}$ (left scale). Accumulated doses as a function of heating temperature - plateau test - are also given (right scale).

90 min at $350^{\circ} \mathrm{C}$, to erase the TL signal, and divided into four aliquots, whose TL was measured after they were irradiated with incremental $\gamma$ doses. Comparisons of TL1 and TL2 growth curves allowed us to compute the accumulated dose of each quartzite specimen as a function of temperature (Fig. 2). For most of the samples, the paleodose was obtained by integrating the $390^{\circ} \mathrm{C}$ peak from 360 to $420^{\circ} \mathrm{C}$ whenever the plateau test was satisfied (Aitken, 1985).

The external dose rate (column 8 , Table 1 ) was measured by means of 13 dosimeters planted for about a year in the relevant archaeological layers of the remaining sections. At each of the three sites the recorded doses had a spread of less than $10 \%$, indicating a homogeneous radioisotope distribution within the relevant sediments. In the Gravetian level of Cardina six dosimeters gave a mean gamma dose rate of $1657 \pm 87 \mu \mathrm{G} / \mathrm{a}$; at Olga Grande Sul four dosimeters gave a mean of $2040 \pm 110 \mu \mathrm{G} / \mathrm{a}$; and at Quinta da Barca three dosimeters yielded a mean of $1670 \pm 65 \mu \mathrm{G} / \mathrm{a}$. For each sample to be dated, we only used the doses measured within a distance of less than $60 \mathrm{~cm}$ in the adjacent meter square.

To calculate the cosmic contribution to the external annual dose, we used the archaeological and geological data obtained during excavation. Since the gradual deposition of sediments modified progressively the burial depth, this factor was taken into account in our estimations of the cosmic dose, which was computed using the formula given by Prescott and Hutton (1994).

$\mathrm{An}$ independent estimate of the external dose was obtained from gamma-spectrometric measurements of radioisotope concentrations in sediment samples collected during excavation. Good agreement was found between gamma radiation doses measured in-situ and those calculated from spectrometric laboratory measurements. The latter also allowed us to verify that the 
Table 1

Radiometric parameters for the dated burnt pebbles ${ }^{\mathrm{a}}$.

\begin{tabular}{|c|c|c|c|c|c|c|c|c|c|c|}
\hline $\begin{array}{l}\text { Sample } \\
\text { Lab. no }\end{array}$ & $\begin{array}{l}\text { Observations } \\
\text { Grain size } \\
(\mu \mathrm{m})\end{array}$ & (ppm) & $\begin{array}{l}\text { Th } \\
\text { (ppm) }\end{array}$ & $\begin{array}{l}K \\
(\%)\end{array}$ & $\begin{array}{l}\text { S-alpha } \\
\mu G y / 1000 \\
\alpha / \mathrm{cm}^{2}\end{array}$ & $\begin{array}{l}\text { Internal } \\
\text { dose } \\
(\mu \mathrm{Gy} / \mathrm{a})\end{array}$ & $\begin{array}{l}\text { External } \\
\text { dose } \\
(\mu \mathrm{Gy} / \mathrm{a})\end{array}$ & $\begin{array}{l}\text { Annual } \\
\text { dose } \\
(\mu \mathrm{Gy} / \mathrm{a})\end{array}$ & $\begin{array}{l}\text { Paleodose } \\
\text { (Gy) }\end{array}$ & $\begin{array}{l}\text { Age } \\
\text { (ka) }\end{array}$ \\
\hline \multicolumn{11}{|l|}{ Cardina } \\
\hline 3 & $100-150$ & 1.112 & 6.574 & 0.193 & 57.3 & $522.8 \pm 18.6$ & $1756.6 \pm 107.0$ & $2279.4 \pm 108.6$ & $63.3 \pm 1.6$ & $27.8 \pm 1.5$ \\
\hline 4 & 100 & 1.528 & 10.641 & 0.227 & 61.8 & $728.3 \pm 28.6$ & $1765.2 \pm 107.0$ & $2493.5 \pm 110.8$ & $69.8 \pm 4.1$ & $28.0 \pm 2.1$ \\
\hline 5 & 50 & 0.674 & 2.287 & 0.260 & 43.7 & $364.4 \pm 38.6$ & $1868.1 \pm 107.0$ & $2232.5 \pm 113.7$ & $46.3 \pm 1.7$ & $20.7 \pm 1.3$ \\
\hline 7 & $80-100$ & 1.475 & 12.086 & 0.530 & 53.2 & $964.0 \pm 48.6$ & $1765.2 \pm 107.0$ & $2729.2 \pm 117.5$ & $82.1 \pm 2.3$ & $30.1 \pm 1.5$ \\
\hline 8 & 120 & 1.066 & 4.474 & 0.142 & 54.5 & $387.8 \pm 58.6$ & $1765.2 \pm 107.0$ & $2153.0 \pm 122.0$ & $50.3 \pm 1.7$ & $23.4 \pm 1.5$ \\
\hline 9 & 700 & 0.621 & 1.461 & 0.592 & 57.5 & $450.3 \pm 68.6$ & $1779.3 \pm 107.0$ & $2229.6 \pm 127.1$ & $60.1 \pm 2.1$ & $27.0 \pm 1.8$ \\
\hline 10 & 150 & 1.911 & 9.086 & 0.432 & 79.6 & $831.0 \pm 78.6$ & $1712.5 \pm 107.0$ & $2543.5 \pm 132.8$ & $67.3 \pm 2.8$ & $26.5 \pm 1.8$ \\
\hline \multicolumn{11}{|c|}{ Olga Grande Sul } \\
\hline 1 & $100-200$ & 0.310 & 1.644 & 0.116 & 65.5 & $218.4 \pm 98.6$ & $1998.2 \pm 128.1$ & $2216.6 \pm 161.7$ & $60.4 \pm 2.4$ & $27.2 \pm 2.3$ \\
\hline 2 & 150 & 0.254 & 1.536 & 0.132 & 60.9 & $214.6 \pm 109$ & $2059.4 \pm 128.1$ & $2274.0 \pm 167.9$ & $68.2 \pm 2.1$ & $30.0 \pm 2.4$ \\
\hline 3 & 150 & 0.867 & 4.378 & 0.180 & 62.6 & $439.3 \pm 119$ & $2161.4 \pm 128.1$ & $2600.7 \pm 174.6$ & $74.0 \pm 3.1$ & $28.5 \pm 2.3$ \\
\hline 5 & 20 & 1.117 & 5.726 & 0.187 & 63.9 & $741.5 \pm 139$ & $2100.2 \pm 128.1$ & $2841.7 \pm 188.7$ & $88.2 \pm 4$ & $31.0 \pm 2.5$ \\
\hline 4 & $400-100$ & 0.472 & 3.353 & 0.063 & 59.4 & $217.1 \pm 129$ & $2018.6 \pm 128.1$ & $2235.7 \pm 181.5$ & $59.9 \pm 1.5$ & $26.8 \pm 2.3$ \\
\hline \multicolumn{11}{|c|}{ Quinta da Barqua } \\
\hline 4 & 150 & 1.006 & 5.086 & 0.153 & 61.3 & $443.2 \pm 169$ & $1791.3 \pm 97.6$ & $2234.4 \pm 194.8$ & $26.7 \pm 0.9$ & $11.9 \pm 1.1$ \\
\hline 3 & 150 & 0.523 & 2.591 & 0.275 & 55.5 & $392.0 \pm 179$ & $1682.7 \pm 97.6$ & $2074.7 \pm 203.5$ & $24.0 \pm 0.7$ & $11.6 \pm 1.2$ \\
\hline 2 & 250 & 1.851 & 4.364 & 1.017 & 121.1 & $1108.7 \pm 189$ & $1766.2 \pm 97.6$ & $2874.9 \pm 212.4$ & $36.4 \pm 1.4$ & $12.7 \pm 1.0$ \\
\hline
\end{tabular}

${ }^{a}(1)$ The average size of the quartz grains was estimated from the examination of thin sections. (2) The uranium, thorium (in ppm) and potassium (\%) concentrations determined by neutron activation analysis; the combined statistical and systematic errors of $\pm 10 \%$ are essentially caused by uncertainties in the reference standards. (3) The Sa value is the alpha sensitivity determined by comparing the TL signal induced by $\alpha$-rays delivered by a 238-Pu source to the TL signal generated by $\beta$-rays from a $90 \mathrm{Sr}$ source. (4) The internal dose was calculated from the U, Th and K contents, the specific dose rates given by Liritzis and Kokkoris (1992), and the attenuation factors computed by Mejdahl (1979). (5) The external dose, calculated by averaging the values recorded by the closest dosimeters (statistical error: $\pm 3 \%$ ), has been corrected to take into account the absorption of the gamma rays passing through the sample (Valladas, 1985). The total error includes a $\pm 5 \%$ uncertainty in the water content of the sediment during the long burial.

Table 2

Activities (dpm/g) of some radioisotops from the Uranium and Thorium series measured by gamma spectrometry

\begin{tabular}{llll} 
& Cardina & Quinta da Barca & Olga Grande Sul \\
\hline $234 \mathrm{Th}$ & $2.6 \pm 0.3$ & $3.3 \pm 0.3$ & \\
$214 \mathrm{Bi}$ & $3.1 \pm 0.1$ & $3.2 \pm 0.1$ & \\
$210 \mathrm{~Pb}$ & $3.7 \pm 0.4$ & $3.1 \pm 0.4$ \\
$228 \mathrm{Ra}$ & $3.0 \pm 0.1$ & $3.2 \pm 0.1$ & \\
$228 \mathrm{Th}$ & $3.0 \pm 0.1$ & $3.4 \pm 0.1$ &
\end{tabular}

uranium and thorium series were in secular equilibria (Table 2), indicating that the radioisotopes did not migrate within the sediments and that the gamma radiation dose rate could not have changed significantly since the lithics were buried. Consequently, one can assume that the external dose rate recorded by the dosimeters probably corresponds closely to the mean rate experienced in the past.

The internal dose rate of each specimen was calculated from the $\mathrm{U}, \mathrm{Th}$, and ${ }^{40} \mathrm{~K}$ concentrations measured by neutron activation analysis (Joron, 1974) at the Pierre Süe Laboratory, Saclay. The pebbles contained between
0.5 and $1.5 \mathrm{ppm}$ of uranium, between 1.4 and $12 \mathrm{ppm}$ of thorium, and less than $0.5 \%$ of potassium. Examination of thin sections of quartzite fragments from Olga Grande and Quinta da Barca revealed that minerals other than quartz were present in very small quantities. In computing the $\alpha$ and $\beta$ doses reeeived by the dated quartz grains we assumed that the $\mathrm{U}, \mathrm{Th}$, and $\mathrm{K}$ concentrations were negligible inside and distributed homogeneously in the surrounding siliceous binder, and we took into account the attenuation factors relevant for the mean grain size in each specimen (Mejdahl, 1979). The internal dose rates (column 7, Table 1) computed for the specimens of these two sites ranged from 10 to $30 \%$ of the total annual rate.

Thin sections of Cardina specimens revealed the presence of minerals rich in uranium and thorium (such as zircon and apatite) in between the grains; the mean distance between these "hot spots" was about $400 \mu \mathrm{m}$. For these quartzite specimens we assumed that the radioisotope concentrations were negligible in the siliceous matrix and that the $U$ and $T h$ were concentrated primarily in the designated minerals. To simplify the calculation of the annual $\alpha$ and $\beta$ doses we considered that the relevant radioisotopes were distributed along the periphery of the quartz grains along a virtual spherical 
surface of a radius of $400 \mu \mathrm{m}$ (mean distance between hot spots) and used attenuation factors of the corresponding granulometry. On the other hand, we assumed that the $K$ concentration was evenly distributed within the binder surrounding the quartz grains. The annual beta dose contributed by the binder was estimated using attenuation factors appropriate for the true mean grain size of each specimen. The computed internal dose rates represented from 20 to $40 \%$ of the total annual rate.

\section{Discussion}

All the age-estimates (column 11, Table 1) are plotted in Fig. 3. The Cardina ages range from $20.7 \pm 1.3$ to $30.1 \pm 1.5 \mathrm{ka}$, with 5 out of 7 clustered in the $26.5-30 \mathrm{ka}$ interval, averaging to $27.9 \pm 1.4 \mathrm{ka}$ (at one sigma). The other two: CAR 5 and 8, were significantly younger, $20.7 \pm 1.3$ and $23.4 \pm 1.5 \mathrm{ka}$ old, respectively. To verify that the radioisotopic distributions assumed in our computation of the internal doses received by the quartz were not responsible for the scatter, we recomputed the ages by assuming that the radioisotopes were homogeneously distributed within the siliceous cement around the quartz grains, as if there were no isolated "hots spots", or else as if the specimens contained no apatite or zircon. The recomputed ages were on the average $4 \%$ younger, yet still within the range of the experimental error. So, it would appear that the scatter of the Cardina results cannot be explained away by an improper estimation of the internal dose rate. The two younger specimens may actually indicate a later, possibly Solutrian, occupation of the site, since a fragment of a Solutrian Laurel Leaf point was found at the limit of the Gravetian level (Aubry, in press).

The ages of the 5 Olga Grande Sul specimens fell between $26.8 \pm 2.3$ and $31.0 \pm 2.5 \mathrm{ka}$, with a mean of $28.7 \pm 1.8 \mathrm{ka}$ (at one sigma). The values suggest that the sites of Olga Grande Sul and Cardina were occupied during the same time interval.

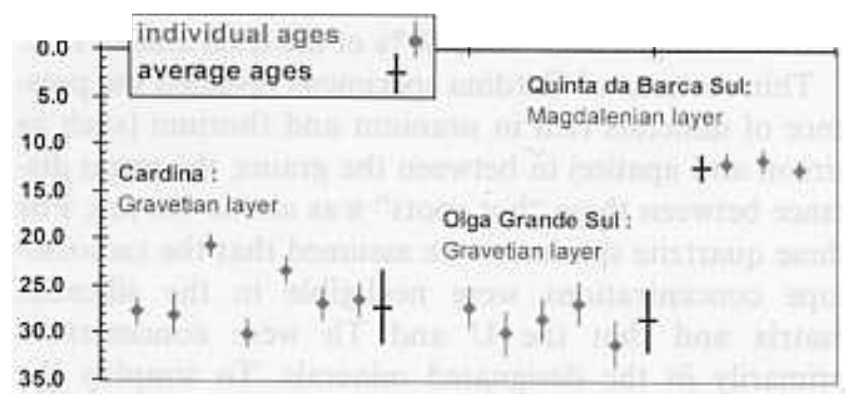

Fig. 3. TL ages of the quartzite specimens from Cardina, Olga Grande Sul and Quinta da Barca Sul. Individual ages and mean values are represented by diamonds and crosses, respectively.
As no radiocarbon data were available for these particular sites, the TL dates can only be compared with calibrated radiocarbon dates obtained for the presumed Gravetian levels at other nearby sites. Thus, at Buraca Escura most of the uncalibrated radiocarbon dates obtained for the level containing lithic industries similar to those of Cardina fell between 22.7 and $23.0 \mathrm{ka}$ (Aubry, in press). The published calibration studies (Voelker et al., 1998 and Kitagawa and Van der Plicht, 1998) suggest that within this time frame the radiocarbon ages underestimate the true age by about $3.5-4 \mathrm{ka}$. Since the corrected date of the Buraca Escura Gravetian industry falls at ca. $27 \mathrm{ka} \mathrm{BP}$, just within the lower limit of the range of TL dates for Cardina (26.5-29.3 ka) and Olga Grande Sul (26.9-30.5 ka), it is possible that the Gravetian of the latter two is slightly more ancient.

The three specimens from the Late Glacial level of Quinta da Barca Sul showed a very small age spread, ranging from $11.6 \pm 1.2$ to $12.7 \pm 1.0 \mathrm{ka}$, with a mean of $12.1 \pm 0.6 \mathrm{ka}$. This date, which places this industry at the end of the Magdalenian period, is quite similar to the calibrated radiocarbon dates for similar industries at the Portuguese Estremadura - between 11 and $12.5 \mathrm{ka} \mathrm{(Au-}$ bry, in press).

\section{Conclusion}

The TL age estimates for the three sites investigated are coherent enough to leave no doubt about the human presence in the Côa Valley during the Gravetian and Magdalenian periods. We plan to continue work on lithic specimens from other levels and sites excavated in the valley in order to get a coherent TL chronology for the entire area.

\section{References}

Aitken, M. J., 1985. Thermoluminescence Dating, Academic Press, London, $359 \mathrm{pp}$.

Bednarik, R., 1997. The Côa petrogliphs: an obituary to the stylistic dating of Paleolithic rock-art. In: Joâo Zilhâo coordenaçâo: Arte Rupestre e Pré - Historia do Vale do Côa, Trabalhos de 1995-1996, Ministério da Cultura do Portugal Editeur, pp. 411-417.

Dorn, R., 1997. Constraining the age of the Côa Valley (Portugal) engravings with radiocarbon dating. In: Joâo Zilhâo coordenaçâo: Arte Rupestre e Pré - Historia do Vale do Côa, Trabalhos de 1995-1996, Ministério da Cultura do Portugal Editeur, pp. 441-454.

Joron, J. L., 1974. Contribution à l'analyse par activation neutronique des éléments en traces dans les roches et les minéraux par activation neutronique. Application à la caractérisation d'objets arche ologiques. Thèse de 3ème cycle, Université Paris, Sud.

Kitagawa, H., Van der Plicht, J., 1998. A 40,000 year varve chronology from the Lake Suigetsu. Japan: extension of the ${ }^{14} \mathrm{C}$ calibration curve, Radiocarbon 40 (1), 505-517.

Liritzis, Y., Kokkoris, M., 1992. Revised dose-rate for TL/ ESR dating. Nuclear Geophysics 6 (3), 123-443. 
Mejdahl, V., 1979. TL dating: beta dose attenuation in quartz grains. Archaeometry 21 (1), 21-26.

Mercier, N., Valladas, H., Valladas, G., 1992. Observations on palaeodose determination with burnt flints. Ancient TL 10, 28-32.

Mercier, N., Valladas, H., Valladas, G., 1995. Flint thermoluminescence Dates from the CFR Laboratory at Gif: contribution to the study of the chronology of the Middle Palaeolithic. Quaternary Science Reviews 14, 351-364.

Prescott, J.R., Hutton, J.T., 1994. Cosmic ray contributions to dose rates for Luminescence and ESR Dating: large depths and longterm time. Radiation Measurements 23 (2/3), 497-500.

Valladas, H., 1981. Etude de la thermoluminescence de grès de foyers préhistoriques. Estimation de leur température de chauffe. Archaeometry 23, 221-229.

Valladas, H., 1985. Datation par la thermoluminescence de gisements moustériens du Sud de la France. Thèse de Doctorat d'Etat,
Muséum national d'Histoire Naturelle et Université de Paris VI, $178 \mathrm{pp}$.

Valladas, H., 1992. Thermoluminescence dating of flint. Quaternary Science Reviews $11(1 / 2), 1-5$.

Valladas, G., Mercier, N, Létuvé, R., 1994. A simple semi-automatic TL apparatus of new design. Ancient TL, 12, 39-40.

Voelker, A. H. L, Starnhein, M., Grootes, P. M., Erlenkeuser, H., Laj, C., Mazaud, A., Nadeau, M. J., Schleicher, M., 1998. Correlation of marine ${ }^{14} \mathrm{C}$ ages from the Nordic Seas with the GISP2 record: implications for ${ }^{14} \mathrm{C}$ calibration beyond $25 \mathrm{ka}$ BP. Radiocarbon 40 (1), 517-535.

Zilhâo, J., 1997. The age of the Côa valley (Portugal) rock art: validation of archaeological dating to the Paleolithic and refutation of «scientific» dating to historic or proto- historic times. In: Joâo Zilhâo coordenaçâo: Arte Rupestre e Pré - Historia do Vale do Côa, Trabalhos de 1995-1996, Ministério da Cultura do Portugal Editeur, pp. 417-436. 